\title{
INSTREAM FLOW AND ATHABASCA OIL SANDS DEVELOPMENT: CONTRACTING OUT/WAIVER OF LEGAL WATER RIGHTS to Protect InSTREAM FloW - A Legal ANAL Ysis
}

\author{
ARLENE J. KWASNIAK*
}

As Alberta Athabasca oil sands development increases, so do the oil sands industry's water requirements from the Athabasca River. In an attempt to address the competing interests of industry's needs and maintain sufficient instream flow in the River to support aquatic ecological needs, Alberta Environment and the federal Department of Fisheries and Oceans developed a Water Management Framework designed to identify and protect instream flow requirements. This article examines the Framework's interaction with legal rights, particularly in the context of licences granted under Alberta water rights legislation. The article raises and analyzes issues concerning the enforceability of the Framework as either a contracting out or waiver of legal rights. As well it considers the effectiveness of the industry agreement made in connection with the Framework. Finally, the article discusses alternative possibilities for reconciling industry's water needs with the protection of the aquatic environment.
Les besoins en eau de la rivière Athabasca (Alberta), de l'industrie des sables bitumineux augmentent avec le développement de ce secteur dans la région. Dans le but d'aborder les intérêts contradictoires des besoins de l'industrie et de maintenir des eaux de ruissellement suffisantes dans la rivière pour répondre aux besoins écologiques aquatiques, Alberta Environment et le ministère fédéral des Pêches et Océans ont préparé un Cadre de gestion conjoint de l'eau pour identifier et protéger les besoins en eaux de ruissellement. Cet article examine l'interaction du document avec les droits juridiques, tout spécialement dans le contexte des permis accordés en vertu de la législation sur les droits d'utilisation de l'eau. L'article analyse et soulève des questions au sujet de la force exécutoire du Cadre comme étant une non-participation ou une décharge des droits juridiques. De plus, l'article prend en compte l'efficacité de l'entente faite avec l'industrie au sujet du Cadre. L'article traite aussi des autres possibilités visant à réconcilier les besoins en eau de l'industrie avec la protection de l'environnement aquatique.

\section{TABLE OF CONTENTS}

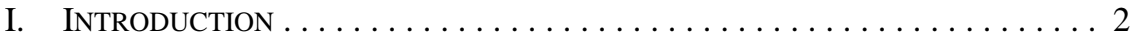

II. ENFORCEABILITY AND REGULATORY BACKSTOPS . . . . . . . . . . 6

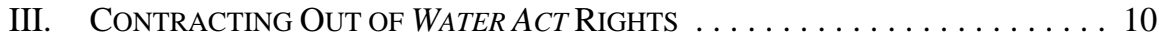

A. The Contracting Out Question $\ldots \ldots \ldots \ldots \ldots \ldots \ldots \ldots \ldots$

B. Contracting Out - The Legal Principles $\ldots \ldots \ldots \ldots \ldots$

C. ENFORCER OF THE INDUSTRY AgREEMENT . . . . . . . . . . . . . 14

D. THE ENFORCEABILITY OF THE INDUSTRY AgREEMENT $\ldots \ldots \ldots \ldots 16$

IV. WAIVER OF WATER ACT Rights . . . . . . . . . . . . . . . . . . 19

A. WAIVER OF STATUTORY RightS . . . . . . . . . . . . . . 19

B. WAS THERE AN EfFective WAIVER? . . . . . . . . . . . . . . . 19

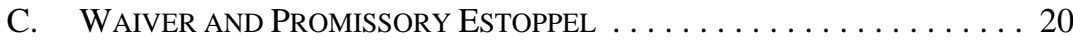

D. THE INDUSTRY AGREEMENT: WAIVER

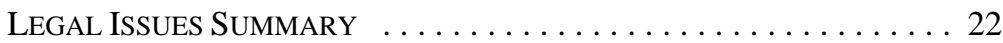

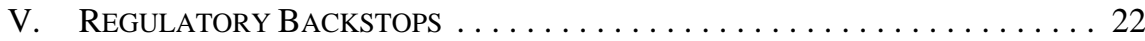

A. REgUlATORY BACKSTOPS AND THE FRAMEWORK . . . . . . . 22

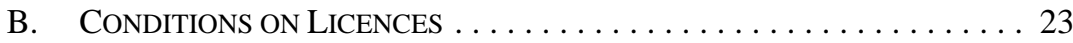

C. Fisheries ACt REQUIREMENTS $\ldots \ldots \ldots \ldots \ldots \ldots \ldots \ldots \ldots \ldots$ 


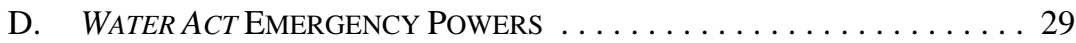

VI. A PATH FORWARD . . . . . . . . . . . . . . . . . . . . . . . . 32

\section{INTRODUCTION}

The undammed Athabasca River originates in the Columbia Glacier in Jasper National Park, near the Alberta/British Columbia border. It is the longest river in Alberta, "winding $1,538 \mathrm{~km}$ through mountains, prairies, forests and muskeg to Lake Athabasca in Wood Buffalo National Park"1 in the northeast corner of the province. Because of its scenic, heritage, and ecological values, in 1989, the Canadian Heritage Rivers Board designated a portion of the river a Canadian Heritage River. ${ }^{2}$ Besides supplying water for municipal needs, the river provides hunting and fishing areas ${ }^{3}$ and heritage values to Dene, Cree, and Métis Aboriginal communities.

Three major areas in northeastern Alberta contain 170 billion barrels of oil proven to be recoverable. ${ }^{4}$ The Athabasca oil sands is the largest. Bitumen production from oil sands is by way of mining or in situ. Both methods require considerable amounts of water. Oil sands near the surface may be mined and trucked to a facility. There, oil sands are mixed with hot water to heat the bitumen and separate it from the sand. Bitumen from deeper oil sands are extracted through in situ processes, primarily steam assisted gravity drainage (SAGD). Here, steam is injected into a well to heat the sands to the point where it can be pumped to the surface. About 80 percent of Alberta's oil sands must be recovered through in situ operations, the balance through mining. ${ }^{5}$ Bitumen is ultimately upgraded into synthetic crude oil.

In 2008, production from the Athabasca oil sands was about 1.31 million barrels of bitumen per day. The Alberta government estimates that this could reach three million barrels per day by 2018. ${ }^{6}$ Although this harkens good news for the Alberta economy, and good news for a world worried about dwindling energy supplies, it threatens bad news for the ecological health of the Athabasca River. The Canadian sustainability think-tank, the Pembina Institute, has stated that "[t]o produce one barrel of oil from oil sands requires 2 to 4.5 barrels of water."7 To produce only one million barrels of bitumen a day requires about the same

Canadian Heritage Rivers System, “Athabasca River Fact Sheet,” online: Canadian Heritage Rivers System <http://www.chrs.ca/Rivers/Athabasca/Athabasca-F_e.htm>.

The Canadian Heritage Rivers (CHR) Board is established under the CHR Charter, a federal/ provincial/territorial national river conservation program. The Charter is designed to promote, protect, and enhance Canada's important heritage rivers, and assist in their being managed sustainably. The 168 kilometre designated section lies entirely within Jasper National Park: see Canadian Heritage Rivers System, "The Canadian Heritage Rivers System," online: Canadian Heritage Rivers System <http://www.chrs.ca/Main_e.htm>.

3 A press release of the Alberta Wilderness Association titled "Athabasca River at Risk" made on 9 February 2010, states that "the Lower Athabasca River provides habitat for 31 species of fish — half the total fish species found in Alberta," online: Alberta Wilderness Association <http://alberta wilderness.ca/news/2010/2010-02-09-awa-news-release-athabasca-river-at-risk>.

4 Government of Alberta, “Alberta's Oil Sands: Facts and stats," online: Government of Alberta <http:// oilsands.alberta.ca/519.cfm>.

Ibid.

Government of Alberta, "Oil Sands," online: Alberta Energy <http://www.energy.gov.ab.ca/Our Business/oilsands.asp>.

Mary Griffiths, Amy Taylor \& Dan Woynillowicz, Troubled Waters, Troubling Trends: Summary Report (Drayton Valley: Pembina Institute for Appropriate Development, 2006) at 2, online: The Pembina Institute <http://pubs.pembina.org/reports/TroubledW7_Summary.pdf > . 
amount of water as sustaining a city of two million people every year. ${ }^{8}$ As of 2005 , the oil sands industry held 76 percent of the surface water allocated through licences for the Athabasca River. This amounts to 8 percent of all water use in Alberta. ${ }^{9}$ Oil sands industry companies are required to recycle some water. As well, companies are investigating, and to an extent using, non-water based SAGD technologies. Nevertheless, it is clear that industry water needs will greatly increase with increased production.

In the Athabasca river basin, as in any other river basin, the instream aquatic environment is a major victim of dwindling fresh water supplies. Reducing water levels to less than present in natural flow regimes normally means a less healthy aquatic environment. If enough water is taken away, the aquatic environment becomes severely impacted and degraded. It is a simple truth that aquatic ecosystems need water. If the instream flow suffers, the aquatic ecosystem suffers. It also is a simple truth that if the aquatic environment is severely compromised, so are the economic, recreational, and cultural values of a watercourse. $^{10}$

In an attempt to deal with the competing interests of industries' increasing water needs and the maintenance of sufficient instream flow in the Athabasca to support ecological instream values ("instream flow needs," "instream flow requirements," or “IFN”), in January 2006, Alberta Environment and the federal Department of Fisheries and Oceans (DFO) announced the Water Management Framework: Instream Flow Needs and Water Management System for the Lower Athabasca River. ${ }^{11}$ Alberta Environment's interest in the Framework is based on the fact that it issues and enforces water rights in the province pursuant to the Alberta Water $A c t^{12}$ and predecessor legislation. ${ }^{13}$ The DFO's interest in the Framework is based on

Dan Woynillowicz \& Chris Severson-Baker, Down to the last drop? The Athabasca River and Oil Sands (Drayton Valley: Pembina Institute for Appropriate Development, 2006) at ii, online: The Pembina Institute $<$ http://pubs.pembina.org/reports/LastDrop_Mar1606c.pdf $>$.

$9 \quad$ David Schindler \& Vic Adamowicz, Running out of Steam? Oil Sands Development and Water Use in the Athabasca River-Watershed: Science and Market based Solutions (Edmonton: Environmental Research and Studies Centre, 2007) at 2, online: The Program on Water Issues <http://powi.ca/ publications.php?17>.

10 Although instream flow is a necessary condition for a healthy aquatic ecosystem (fish and aquatic habitat need water) there are many other values that are achieved or enhanced by restoring and protecting instream water. The North America Instream Flow Council's third book on instream flow, T. Annear et al., Integrated Approaches to Riverine Resource Stewardship: Case Studies, Science, Law, People, and Policy (Cheyenne: Instream Flow Council, 2008) at 1, summarizes some of the other reasons why flowing rivers are important: "Rivers have provided sustenance and economic inputs for centuries. They drive grist mills and power entire civilizations. They move commerce from seaports inland and back. Rivers provide inspiration for song, poems, cultural traditions, child's play, and religious rites. Humans are more strongly drawn to flowing water than any other physical feature on Earth."

11 Alberta Environment \& Fisheries and Oceans Canada, Water Management Framework: Instream Flow Needs and Water Management System for the Lower Athabasca River (Edmonton: Alberta Environment, 2007), online: Alberta Environment <http://environment.alberta.ca/documents/Athabasca_RWMF_ Technical.pdf $>$ [Framework]. The Framework defines "Instream Flow Needs/ Instream Needs" as "the amount of water, flow rate, water level, or water quality that is required in a river or other body of water to sustain a healthy aquatic ecosystem" (at 22).

12 R.S.A. 2000, c. W-3.

13 The first water rights legislation applicable to what is now Alberta was the federal North-west Irrigation Act, S.C. 1894, c. 30 [NIA]. After the transfer of public lands and natural resources from the federal government to the prairie provinces in 1930, Manitoba, Saskatchewan, and Alberta assumed legislative jurisdiction over water: see Natural Resources Transfer Agreements, being Schedules to the Constitution Act, 1930 (U.K.), 20 \& 21 Geo. V, c. 26, s. 13, reprinted in R.S.C. 1985, App. II, No. 26. In 1931, Alberta passed The Water Resources Act, S.A. 1931, c. 71. The final consolidation of this Act was the Water Resources Act, R.S.A. 1980, c. W-5. The Water Resources Act was repealed and replaced by the Water Act, ibid., which came into effect in 1999. 
the fact that it has exclusive constitutional legislative jurisdiction over inland fisheries, ${ }^{14}$ including the Athabasca basin fisheries, and that, pursuant to this jurisdiction it administers and enforces the federal Fisheries Act. ${ }^{15}$ In part, this Act is designed to protect fish habitat. Section 35 of the Act requires works or undertakings that will cause a "harmful alteration, disruption or destruction of fish habitat" to obtain authorization under the Act or else be open to prosecution. ${ }^{16}$ The federal government interprets s. 35 as applying to water withdrawals, including those under provincial authorization.

The Framework consists of two phases. Phase 1 establishes interim instream flow requirements for reaches of the Athabasca River and proposes voluntary management actions dependant upon the rate of flow at a given time. Management actions are based on the presence of one of three river flow conditions - green, yellow, or red — for each week of the year. Green represents when the river flow is above a cautionary threshold (CT). Yellow is below the CT but above a minimum specified flow amount. Red is below the CT and below a minimum specified flow amount. In green conditions, all licensees may operate within the terms of their licences. In yellow conditions, licensees are "required" to "voluntarily" share water and respect cumulatively limited withdrawals in a specified amount depending upon season and spawning conditions. In red conditions, the Framework proposes more stringent cumulative withdrawal conditions. ${ }^{17}$ The Framework anticipates that the various industry oil sands companies withdrawing water from the Athabasca River enter into a separate agreement incorporating the major provisions of the Framework. This article calls this agreement the "Industry Agreement” or "Agreement” and the companies that signed the Agreement the "industry signatories." 18

Phase 2 of the Framework, which is currently under development, will refine IFNs, "prescribe when, and how much, water can be withdrawn from the Lower Athabasca River for cumulative oil sands mining water use,"19 and establish "regulatory backstops." 20 Regulatory backstops are regulatory actions that government may take to enforce the Framework should the industry players fail to adhere to the Framework or Industry Agreement.

The Framework is remarkable in that it flies in the face of the legal water rights system under the Water Act. Licenced water rights under the Water Act, similar to western United States state water rights, are based on “first in time, first in right” (FTFR). The Alberta FTFR

14 This jurisdiction is pursuant to the Constitution Act, 1867 (U.K.), 30 \& 31 Vict., c. 3, s. 91(12), reprinted in R.S.C. 1985, App. II, No. 5.

R.S.C. 1985, c. F-14.

Ibid.

Framework, supra note 11 at 10.

Letter from Don Thompson, President, The Oil Sands Developers Group, to Ernie Hui, Assistant Deputy Minister, Alberta Environment \& Bob Lambe, Regional Director General, Central and Arctic Region, Fisheries and Oceans Canada, "Re: Oil Sands Mining Water Management Agreement for the 2008-2009 Winter Period” (10 December 2008), online: Alberta Environment < http://www.environment.alberta.ca/ documents/Oil-Sands-Water-Mgt-Agreement-winter-2008-09.pdf>.

19 Don Ohlson et al., Phase 2 Framework Committee Report (Fort McMurray: Cumulative Environmental Management Association, 2010) at i, online: Cumulative Environmental Management Association <http://cemaonline.ca/component/docman/doc_download/2305-press-release-phase-2-frameworkcommittee-report-and-appendices.html>. The Phase 2 Framework Committee was a multi-stakeholder group initiated by the Alberta government and formed in 2008 to develop recommendations for Phase 2 of the Framework.

Framework, supra note 11 at 4. 
water rights system dates back to the federal North-west Irrigation Act of $1894 .^{21}$ Although the Water Act authorizes water sharing agreements to "share the shortage" so that licensees may assign water to other licensees and authorized water users, ${ }^{22}$ there is nothing in the provisions that would enable, in effect, an assignment to the river itself to maintain instream flows. In fact the Water Act, just like predecessor legislation, enables licensees to exercise their rights to withdraw water in accordance with the terms and conditions of their licences, based on FTFR, and with pre-1999 licences, regardless of consequences to the aquatic environment. ${ }^{23}$ As will be discussed in greater detail below, only newer licences (issued in the last few decades) contain minimum flow conditions, meaning conditions that allow water withdrawals only when there is a specified minimum flow in the water source. However, there is evidence that such minimum flow conditions are considerably lower than established instream flow requirements. ${ }^{24}$ With respect to the Lower Athabasca River and oil sands licensees, although it is expected that new licences will contain conditions that reflect the Framework's reductions on withdrawals requirements, pre-Framework licences do not impose these requirements. Pre-Framework licences notably include Suncor Energy Inc.'s (Suncor) 1965 and 1979 licences for, cumulatively, 48,500 acre feet of water a year, ${ }^{25}$ and Syncrude Canada Ltd.’s (Syncrude) 1973 licence for 50,000 acre feet of water a year. ${ }^{26}$ PreFramework licensees have the legal right to withdraw water in accordance with their licences, even where withdrawals would violate the Framework or Industry Agreement. Since pre-Framework licences do not, as a legal condition, require compliance with the Framework, the Framework and Industry Agreement are, in effect, a contracting out or waiver of aspects of the legislated water rights framework in the Water Act and licence entitlements of pre-Framework licences.

This article explores the Framework and Industry Agreement as a solution to competing industry needs versus instream flow needs in the context of uncooperative legislation and entrenched water rights. Part II of the article argues that the Framework and Industry Agreement are a viable solution only if the Industry Agreement is enforceable, or if there is an appropriate regulatory backstop. These issues are important not only with respect to the protection of the Athabasca River. They have application in general to the enforceability of voluntary compliance agreements that governments enter into with industry in lieu of regulation. ${ }^{27}$ Part III of the article explores the legal aspects of the Framework and Industry

NIA, supra note 13.

Supra note 12 , s. 33.

Ibid., s. 18. This claim is subject to the following: the Water Act came into effect in 1999. Licences issued under the Water Act (post-1999 licences) may be amended by government if "an adverse effect on the aquatic environment occurred, occurs or may occur that was not reasonably foreseeable at the time the licence was issued, and compensation may be payable under section 158” (s. 54(2)). Compensation may be payable. Note that post-1999 licences will typically be very junior. Generally, it is more senior licences that will pose problems for IFNs.

24 Michael M. Wenig, Arlene J. Kwasniak \& Michael S. Quinn, "Water under the Bridge?: The Role of Instream Flow Needs (IFNs) Determinations in Alberta’s River Management” in H. Epp \& D. Ealey, eds., Water: Science and Politics, Proceedings of the Conference Held by the Alberta Society of Professional Biologists (Edmonton: Alberta Society of Professional Biologists, 2007) at 19.

25 Alberta Environment, Licence No. 11403, Athabasca River, issued to Suncor Inc. (8 June 1987), online: Alberta Environment <http://envext02.env.gov.ab.ca/pdf/00038538-00-00.pdf> [Suncor Licence].

26 Alberta Environment, Licence No. 15607, Athabasca River, issued to Syncrude Canada Ltd. (20 October 1986), online: Alberta Environment <http://envext02.env.gov.ab.ca/pdf/00035216-00-00.pdf> [Syncrude Licence].

27 There are numerous examples of cases where a North American government has chosen to enter into a voluntary compliance agreement rather than to regulate. Here are two. The first is Accelerated Reduction/Elimination of Toxics (ARET), a federal program initiated in 1993 aimed at the virtual elimination or reduction of certain persistent, bioaccumulative, and toxic substances. Some of these 
Agreement, conceived as a contracting out. It concludes that a court likely would not uphold the Industry Agreement as a valid contracting out of aspects of the Water Act and of licence rights, and would likely find the Act and water rights to prevail over the contract. Part III also considers whether the Industry Agreement is enforceable as a contract and, if so, by whom. It concludes that if enforceable, it is only enforceable by the parties to it, through lawsuit, and that it is unlikely that government has the capacity to become an effective party to the Agreement. Further, Part III discusses whether the Agreement effectively incorporates the main provisions of the Framework and concludes that the Agreement exhibits weaknesses in this regard. Part IV moves from contracting out to waiver. It considers whether a court would uphold the Framework and Industry Agreement as a waiver of legal rights under the Water Act and the applicable industry licences. The Part concludes that a court likely would find that they are not. Part V considers to what extent it is possible to have an effective "regulatory backstop" through the current Water Act and federal authority in the Fisheries Act. It concludes that there does not seem to be regulatory backstops sufficient to compel compliance with the Framework. ${ }^{28}$ The Part also discusses Water Act emergency powers as Alberta Environment Minister Rob Renner recently discussed them in the context of Phase 2 of the Framework. ${ }^{29}$ The Part concludes that Water Act emergency powers do not provide a wholly adequate regulatory backstop. Part VI discusses possible paths forward to better reconcile the oil and gas industry's water needs with protection of the public interest through enforceable limitations on water withdrawals aimed at protecting instream flow needs. These include amendments to the Water Act to permit contracting out or waiver arrangements, and voluntary amendments to oil sands industries' Water Act licences aimed at instream flow protection.

\section{ENFORCEABILITY AND REGULATORY BACKSTOPS}

The author is not aware of any evidence that the industry signatories will decide not to comply with the Framework and Industry Agreement. Nevertheless, for several reasons it is critical that the Framework and Industry Agreement either be legally enforceable or that there are appropriate regulatory backstops.

First, if government is to rely on non-regulatory instruments to protect public or private interests in resources, rights, or values instead of regulating protection, government must be able to assure the public and those directly affected by this choice that the non-regulatory

substances are listed on a schedule to the Canadian Environmental Protection Act, 1999, S.C. 1999, c. 33, Sch. 1, or its predecessor the Canadian Environmental Protection Act, R.S.C. 1985 (4th Supp.), c. 16 , in effect when the ARET program began and therefore within the power of the federal government to regulate. For a restrospect on the ARET program, see Environment Canada, "Follow-up to the Evaluation of the Accelerated Reduction and Elimination of Toxics Initiative (ARET),” online: Environment Canada <http://www.ec.gc.ca/ae-ve/default.asp?lang=En\&n=7F6D17C5\&offset=2\&toc= show $>$. The second is a Memorandum of Understanding between the Air Transport Association of Canada (ATAC) and the Federal Minister of Transport, which administers the federal Aeronautics Act, R.S.C. 1985, c. A-2, under which the ATAC, on behalf of ATAC members, agrees to voluntarily reduce greenhouse gas emissions by improving fuel efficiency: see ATAC, Voluntary Agreement on the Reduction of Greenhouse Gas Emissions: 2006 Annual Report (Ottawa: Air Transport Association of Canada, 2008), online: Transport Canada <http://www.tc.gc.ca/media/documents/programs/2006atac. pdf $>$.

28 I thank third year University of Calgary law student Jane Butcher for her excellent research regarding some of the issues discussed in Parts III, IV, and V of this article. I also thank the Social Sciences and Humanities Research Council of Canada for funding some of the research for the article. Dan Healing, "Minister vows action on oilsands water" Calgary Herald (8 February 2010) C4. 
instruments are enforceable or that there are appropriate regulatory backstops. It is irrelevant what the non-regulatory instruments are or whether those who commit to them would, in fact, renege on commitments. However, it is relevant that government be able to defend and justify a policy choice not to regulate and instead rely on voluntary arrangements.

Second, in the past an oil sands industry player reneged on obligations in a voluntary agreement with no consequences to it. There is no certainty that this will not happen again. The agreement concerned Albian Sands Energy Inc.'s (Albian) 2003 application to expand the Muskeg River Mine, which included the development of Shell Canada Limited's (Shell) Jackpine Mine. This Athabasca oil sands project is located about 70 kilometres north of Fort McMurray, Alberta. The project required both federal and provincial approvals, including an approval from the Alberta Energy and Utilities Board (EUB), now the Energy Resources Conservation Board (ERCB), and involved a joint panel environmental assessment by the EUB and the Government of Canada (the Joint Panel) under the federal Canadian Environmental Assessment $A c t^{30}$ and the provincial Environmental Protection and Enhancement Act. ${ }^{31}$ In the context of the environmental assessment and approval processes, Shell entered into a written agreement called the "Issue Resolution Document" with the Oil Sands Environmental Coalition (OSEC). ${ }^{32}$ In the Issue Resolution Document, Shell agreed to establish a greenhouse gas emission reduction target for the Jackpine Mine designed to reduce emissions to exceed reductions of the most likely commercial alternative on a full cycle basis. ${ }^{33}$ The Issues Resolution Document was submitted to the Joint Panel as evidence in connection with the environmental assessment of the project. ${ }^{34}$ A Shell representative testified at the Joint Panel hearing as to the importance of the commitments ${ }^{35}$ made to OSEC. ${ }^{36}$ As a result of the agreement contained in the Document and other commitments made by Shell, OSEC did not call evidence at the hearing regarding GHGs relating to the Jackpine Mine. ${ }^{37}$ The Joint Panel acknowledged these agreements and stated that it expected "Albian to meet its commitments and continue its consultation and communication efforts throughout the life of the project." 38 However, in the end, Shell failed to meet its commitments. ${ }^{39}$ OSEC unsuccessfully applied to the ERCB to reopen its decision to approve

\section{S.C. 1992 , c. 37.}

R.S.A. 2000, c. E-12 [EPEA].

The Pembina Institute for Appropriate Development notes that OSEC consists of "Alberta-based environmental organizations concerned about the cumulative and project-specific environmental and socioeconomic impacts of oil sands development.” OSEC has "been engaged in reviewing and assessing oil sands projects since the mid-1980s.” Members include the Pembina Institute, Toxics Watch Society of Alberta, and the Fort McMurray Environmental Association: Pembina Institute, Media Release, "Shell Breaks Global Warming Promise for Oil Sands Projects” (8 April 2009), online: The Pembina Institute $<$ http://www.pembina.org/media-release/1808>.

33 According to the Pembina Institute, ibid., “[w]ithout these commitments, Shell's GHG [greenhouse gas] pollution from these projects will increase by an estimated 900,000 tonnes, which is equivalent to adding 200,000 cars to the road in Canada."

$34 \quad$ Pembina Institute for Appropriate Development v. Alberta (Energy Resources Conservation Board), 2009 ABCA 322, [2009] A.J. No. 1035 (QL) [Pembina Institute] (Evidence, affidavit of Daniel Woynillowicz of the Pembina Institute at para. 3) [Woynillowicz Affidavit].

35 The Woynillowicz Affidavit, ibid. at para. 7, states that at the hearing Shell tendered a document in evidence entitled "Commitment List." At page 5 of this List, Shell committed to "establishing energy efficiency objectives annually to reduce $\mathrm{CO}_{2}$ emissions.”

Ibid. at para. 7 .

Ibid. at para. 9.

Albian Sands Energy Inc.: Application to Expand the Oil Sands Mining and Processing Plant Facilities at the Muskeg River Mine, EUB \& Canadian Environmental Assessment Agency Joint Review Panel Decision 2006-128 (17 December 2006) at 7.2.5. All EUB and ERCB decisions are available online: ERCB <http://www.ercb.ca/portal/server.pt?>. 
the project. ${ }^{40}$ Its application for leave to the Alberta Court of Appeal failed on the basis that the application neglected to raise a question of law or jurisdiction. ${ }^{41}$

The third reason concerns the fact that the industry signatories are corporations. As philosopher Christopher Stone said in 1975, a corporation "is a persona ficta, a 'legal fiction' with 'no pants to kick or soul to damn', ${ }^{42}$ and "overwhelmingly a profit maximizer." ${ }^{43}$ Stone notes that corporate goals are first to survive and, assuming survival, to make a satisfactory profit and second, "to stave off shareholder insurrections." ${ }^{44}$ Once these two goals are attained, a corporation may seek "higher" ones such as "expansion, prestige, innovation" and an "exciting internal environment." ${ }^{45}$ Only after attaining the higher goals may a corporation display an increasing "social orientation" such as sponsoring cultural events. ${ }^{46}$

More recently, in 2007, legal theoretician Paul Hohnen made a strong business case for corporate social responsibility in order to maximize profits and minimize risk. To summarize Hohnen, by incorporating social responsibility into day-to-day operations, corporations can improve reputation management, enhance their ability to recruit, develop, and retain staff, improve innovation, competitiveness, and market positioning, enhance operational efficiencies and cost savings, improve their ability to attract and build effective and efficient supply chain relationships, enhance their ability to address change, and provide a more robust "social licence" to operate in the community. ${ }^{47}$

Applying Stone's and Hohnen's analyses, a corporation voluntarily entering into the Industry Agreement and agreeing to comply with the Framework would fit either under Stone's higher goal, or under Hohnen's primary goal of a corporation: to maximize profits and to minimize risk. Now consider what would happen if, in a dry, low flow year, compliance with the Framework and Industry Agreement no longer contributed to maximized profits or minimized risk. What if an industry signatory would have to decrease or even shut down operations because of a lack of water and hence lose profits if it complied with the Framework and Industry Agreement? ${ }^{48}$ Assuming for the moment that risk in relation to non-compliance is not an issue, unless the Industry Agreement is appropriately enforceable or there is an effective regulatory backstop, on either Stone's or Hohnen's

The Energy Resources Conservation Act, R.S.A. 2000, c. E-10, s. 39, states that the Board may by order "review, rescind, change, alter or vary an order or direction made by it, or may rehear an application before deciding it.” The Board has limited this authority to situations where there is new evidence or the applicant has alleged an error of law, jurisdiction, or fact, or has raised a substantial doubt as to the correctness of the Board's original decision: see e.g. Letter from Dan McFadyen, Chairman, ERCB to Karin Buss, Ecojustice, “Application Under Section 39 of the Energy Resources Conservation Act (ERCA) by the Oil Sands Environmental Coalition (OSEC) In The Matter of the Joint Panel Report and EUB Decision 2004-009 (Decision 2004-009) Shell Canada Limited (Shell) Jackpine Mine Project Review, Application No. 1611619” (11 June 2009) at 2. Pembina Institute, supra note 34 at para. 7.

42 Christopher D. Stone, Where the Law Ends: The Social Control of Corporate Behavior (New York: Harper \& Row, 1975) at 3. To support the quoted portions, Stone refers to H.L. Mencken, A New Dictionary of Quotations on Historical Principles from Ancient and Modern Sources (New York: A.A. Knopf, 1942) at 223.

43 Stone, ibid. at 39.

$44 \quad$ Ibid. at 38.

Ibid. at 39.

Ibid.

Paul Hohnen, Corporate Social Responsibility: An Implementation Guide for Business, ed. by Jason Potts (Winnipeg: International Institute for Sustainable Development, 2007) at 11.

48 This is not a speculative scenario. Ohlson et al., supra note 19, reflect industry's concern for its water needs, including regarding the relation between its water needs and corporate profits. 
analysis, by virtue of the nature of a corporation the industry signatory would likely choose profits over compliance.

Now consider Hohnen's risk element. What would the risk of non-compliance be if the Framework and Industry Agreement are not enforceable and there is not an appropriate regulatory backstop? If there is no breach of the law, government penalty, or other legal repercussion, then the obvious risk would be the consequences for the corporation's reputation as a social entity. Whether the corporation would choose to comply or not comply in light of such risk cannot be answered in advance of a risk analysis pertinent to a particular situation. However, the oil sands industry has taken positions that damaged corporate social reputation in the past. An example is Syncrude pleading not guilty to charges under the Alberta EPEA and the federal Migratory Birds Convention Act, $1994^{49}$ relating to the 2008 death of 1,606 ducks in its tailings pond north of Fort McMurray. ${ }^{50}$ Syncrude plead not guilty notwithstanding that it acknowledged that the birds died in its tailing pond and that the loss of wildlife was "completely unacceptable." 51 In addition, at a court appearance on 10 June 2010, Syncrude gave notice of a possible constitutional challenge, presumably to the validity of the Migratory Birds Convention Act, $1994 .^{52}$ An internet search revealed considerable negative response to Syncrude's pleading not guilty and possible challenge of the federal legislation. ${ }^{53}$

To be clear, without question Syncrude has every right to defend itself against the charges and to constitutionally challenge legislation, if that is what it intends to do. The point merely is that given the international scrutiny of the Alberta oil sands and amidst allegations of "dirty oil," 54 Syncrude, which no doubt carried out a risk analysis in deciding whether to contest the charges, chose a course of action that carried negative social consequences.

\section{S.C. 1994 , c. 22.}

The trial begins 1 March 2010 and will be held in St. Albert, Alberta. Two months have been reserved for it.

See Sarah O’Donnell, “Syncrude pleads not guilty in dead ducks case” Edmonton Journal (14 September 2009), online: Calgary Herald <http://www.calgaryherald.com/business/Syncrude+pleads+ guilty+dead+ducks+case/1992697/story.html>.

For a discussion of this matter, see Jocelyn Stacey, "Lame duck constitutional arguments: a new twist on Syncrude's Tailings Pond Debacle” ABlawg (30 June 2009), online: The University of Calgary Faculty of Law Blog on Developments in Alberta Law <http://ablawg.ca/2009/06/30/lame-duckconstitutional-arguments-a-new-twist-on-syncrude's-tailings-pond-debacle/>.

The comments range from a northern Aboriginal Facebook blog "People Against Syncrude's Dead Duck Solutions," online: Facebook <http://www.facebook.com/group.php?gid=74612390891>, to a newspaper article in Fort McMurray Today which comments that "critics of Syncrude's decision to plead not guilty say that a more sincere gesture of them feeling bad about the bird deaths would be a guilty plea": see Roland Cilliers, "Syncrude pleads not guilty to duck deaths” Fort McMurray Today, online: Fort McMurray Today <http://www.fortmcmurraytoday.com/ArticleDisplay.aspx?archive=true $\& \mathrm{e}=1754117>$, to strong statements such as that of Greenpeace: see Bruce Cox, "Will Syncrude Duck Responsibility?” (14 September 2009), online: Greenpeace <http://www.greenpeace.org/Canada/ en/Blog/update-will-syncrude-duck-responsibility/blog/3933>:

I think Canadians would be rightfully angered at the thought of two months of court time being used in order for Syncrude investors like Petro Canada and Imperial Oil to duck their responsibilities. I think Canadians will be offended by Syncrude raising [CONSTITUTIONAL] loopholes in order to challenge the authority of the Canadian government to protect wildlife and our environment. Syncrude does not deny 1,600 ducks died in their tailing pond. They just don't wish to be punished for it.

See e.g. Andrew Nikiforuk, Tar Sands: Dirty Oil and the Future of a Continent (Vancouver: Greystone Books, 2010). 


\section{Contracting OUT OF WATER ACt RightS}

\section{A. The Contracting Out Question}

A key question regarding the Industry Agreement is whether it is enforceable at law given that it includes a contracting out of water rights under the Water Act. Answering this question depends on answering the more general one of whether a Water Act water licence holder may, at law, legally contract out of Water Act and licence rights; in particular, the right to divert water in accordance with the Act and the conditions and terms contained in the licences. Responding to the latter question with a "yes" would mean that if an industry signatory chose to fully enforce its Water Act rights in a situation where the Industry Agreement would disallow it (for example, a yellow or red Framework condition), in the end the Industry Agreement would prevail, and not the party's water rights per se. In other words, a court would find that the Industry Agreement was a legal and enforceable contract that overrode rights under the Water Act.

\section{B. Contracting Out - The Legal Principles}

A review of the Canadian case law on contracting out elicits several legal principles. The core principle ${ }^{55}$ regarding contracting out is that it is permissible if:
A. the statute in question does not expressly or impliedly prohibit contracting out,
B. the contracting out is in direct and clear language,
C. the contracting out is not in relation to public and fundamental law, and
D. the statutory provisions in question are for a private benefit; one cannot contract out of regulatory provisions imposed in the public interest.

How do these principles apply to the situation involving the Water Act, licences issued under the Act, the Framework, and the Industry Agreement?

Regarding A, nothing in the Water Act expressly prohibits contracting out. Nothing in the Act expressly prohibits a licensee from contracting with other licensees to cumulatively restrict withdrawals in given situations, even if they would have a right to divert water in excess of these restrictions in accordance with the Act and their licence terms and conditions. Nevertheless, an argument may be made that the Act impliedly prohibits this kind of contracting out. The implied prohibition is based on the fact, as mentioned above, ${ }^{56}$ that the Water Act expressly authorizes a licensee to temporarily assign, for a period of time, all or part of an allocation when specific statutory conditions are met. ${ }^{57}$ These conditions include that there be a water shortage such that, in the absence of an assignment, the assignee would not be able to divert the entire licenced allocation. ${ }^{58}$ In other words, the Water Act allows a 
more senior licensee to assign all or part of an allocation to a more junior licensee only when there is not enough water for all allocations to be satisfied. The statutory assignment provisions only apply when there is a water shortage in the sense that there simply is not enough water to satisfy all licensees' entitlements in accordance with their licences. It has nothing to do with water entitlements determined by some other means, such as the Framework or the Industry Agreement.

Licenced water rights in Alberta only consist of what is prescribed as a water right in the Water Act and its regulations, and in valid licence terms or conditions. By application of the expressio unius est exclusio alterius rule of statutory interpretation, which holds that the express mention of one thing excludes another, the Water Act assignment provisions are the only way that licensees may contract out of what would otherwise be their statutory water rights where there are limited water supplies. Accordingly, there is a good argument that the Water Act implicitly prohibits contracting out of water entitlements in the manner contemplated by the Industry Agreement.

Regarding B, a contracting out must be in direct and clear language. A review of the Industry Agreement reveals that this requirement has not been met. The Agreement does not mention the Water Act or any statutory water rights. Case law makes it clear that any contracting out must be explicit. ${ }^{59}$

Regarding C, a "public and fundamental law" is a law that sets forth a public policy on a matter. It typically protects a core matter of public welfare or interest. Human rights legislation and provisions meant to protect the public in legislation are examples. ${ }^{60}$ Cases make it clear that a person may not contract out of equality rights, notice of termination rights, and similar provisions. The question becomes, is the water management FTFR schema set forth in the Water Act a public and fundamental law such that it would be against public policy for licensees to contract out of it? Although this question cannot be answered definitively here, some observations may be made.

Although the Water Act and predecessor legislation confer private rights, the legislative schema inherent in the Act is public law pertaining to a public resource ${ }^{61}$ Whether the water rights legislative schema constitutes fundamental public law is not clear, but there are reasons why a court might find that the schema is fundamental public law. Consider the following. The entire water management legal schema seems to be fundamental public law, the core principles of which were set out in statute in 1894 to essentially replace the prevailing common law riparian rights framework. ${ }^{62}$ The legislative schema does not merely consist of

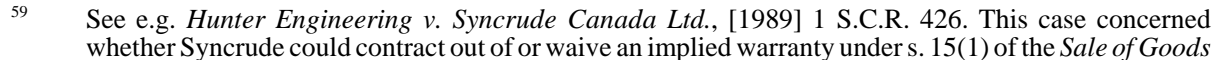
Act, R.S.O. 1970, c. 421. Section 15(4) of the Act expressly allowed waiver of statutory implied warranties. The Court found that there was an explicit waiver of the statutory warranty in the contract. The Court relied on Chabot v. Ford Motor Co. of Canada Ltd. (1982), 39 O.R. (2d) 162 (H.C.).

60 See e.g. Ontario (Human Rights Commission) v. Etobicoke (Borough of), [1982]1 S.C.R. 202; Dickason v. University of Alberta, [1992] 2 S.C.R. 1103; Insurance Corp. of British Columbia v. Heerspink, [1982] 2 S.C.R. 145, where Lamer J. (as he then was) wrote at 158: "Furthermore, as [the Human Rights Code] is a public and fundamental law, no one, unless clearly authorized by law to do so, may contractually agree to suspend its operation and thereby put oneself beyond the reach of its protection."

61 This is further discussed under Part III.D, below.
62 The NIA, supra note 13, sets out the FTFR water rights legal system for the Northwest Territories, Manitoba, and what would become Alberta and Saskatchewan. 
isolated legislative provisions of general application. It consists of an entire water management framework meant to comprehensively govern both public and private interests in water. It is fundamental in that the constitutive protections and elements of actual and potential public and private interests in water are given by this framework. ${ }^{63}$

Principle D is key to this discussion. The principle has two parts. First, it requires that the statutory provisions be designed to regulate private rights only. Although applying to waiver, this principle may equally apply to contracting out. It is succinctly summarized by PierreAndré Côté in The Interpretation of Legislation in Canada: ${ }^{64}$

\begin{abstract}
An individual may waive the benefit of a right enacted in his favour: quilibet licet renuntiare juri pro se introducto. Application of this general principle is confined to situations where the statute has been enacted in the sole interest of one individual or of a category of individuals. But it is not possible to dispense with a statute which has been partially or entirely adopted in the public interest.
\end{abstract}

In City of Toronto v. Russell, the Privy Council held that a taxpayer could waive the right to receive a notice of the sale of his immoveables for non-payment of taxes. The notice was required by law for the sole protection of the owner. Russell had waived his right, not expressly or in written form, but simply by his behaviour.

More recently, it was held that a taxpayer can validly waive his right to appeal an assessment made for income tax purposes. The taxpayer had, in writing, admitted his liability to taxation. Collier J. said:

... the taxpayer's right to appeal assessments is a private right, and not a public right in the sense that the appeal provisions in the Act express a public policy. ${ }^{65}$

An argument could be made that a Water Act licenced allocation is a private right given by statute, and therefore a right to the entire allocation legally may be contracted out of by the licence holder. However, there is a compelling counter-argument that a water licence is more than just a private right. A water right reflects and is tempered by a complex legislated public law system that has developed over more than a century to manage water - a public resource - in the public interest. The purposes of the Water Act evidence the broad public interest context of water rights:

The purpose of this Act is to support and promote the conservation and management of water, including the wise allocation and use of water, while recognizing

(a) the need to manage and conserve water resources to sustain our environment and to ensure a healthy environment and high quality of life in the present and the future;

Compare Alberta FTFR rights to western U.S. jurisdictions where FTFR water rights are protected by constitution, e.g., Colo. Rev. Stat. tit. $37 \S \S 80-92$; Colo. Const. art. XVI, §§ 5-6. In such jurisdictions, water rights principles surely would constitute fundamental public law that cannot be contracted out of. The question is, does the fact of constitutional entrenchment make such a difference that the FTFR schema in Colorado is fundamental public law, but the Alberta FTFR schema is not fundamental public law? Ibid. at 241-42 [footnotes omitted]. 
(b) the need for Alberta's economic growth and prosperity;

(c) the need for an integrated approach and comprehensive, flexible administration and management systems based on sound planning, regulatory actions and market forces;

(d) the shared responsibility of all residents of Alberta for the conservation and wise use of water and their role in providing advice with respect to water management planning and decision-making;

(e) the importance of working co-operatively with the governments of other jurisdictions with respect to transboundary water management;

(f) the important role of comprehensive and responsive action in administering this Act. ${ }^{66}$

The purposes reflect that FTFR water rights are far more complex and immersed with public policy than Côté's examples: a right to receive notice of a sale of property, and a right to appeal a finding of liability after an admission of liability.

This takes us to the second part of principle $\mathrm{D}$, that one cannot contract out of regulatory provisions imposed in the public interest. Case law examples include:

- An employee cannot contract out of the statutory minimum notice of termination requirements set in the Ontario Employment Standards Act. ${ }^{67}$

- A client of a law firm cannot contract out of the statutory 30 day window to register a complaint about a lawyer's account, thus rendering a 15 day period in a retainer agreement to be null and void. ${ }^{68}$

- A person cannot contract out of statutory rights to redeem a mortgage. ${ }^{69}$

In each of the above situations a person's contracting out was held to be void, or at least unenforceable against the person. For instance, regarding the third example, a court found that where legislation gave a right to pay off a mortgage at the end of a five year period a mortgagee's purported relinquishment of this right could not be enforced against him. ${ }^{70}$

Applying this to the situation at hand, the question is, are the Water Act's provisions that bestow the right to an allocation set out in a licence in accordance with the Act and the licence terms and conditions, established, at least in part, in the public interest, or do the statutory provisions solely serve private interests? This question raises the more general one of how one determines whether statutory provisions are imposed to serve private interests only, or whether they are also imposed to serve the public interest. 
An example of a statute that a court found to be made solely to serve private interests is the Northwest Territories' Condominium Act. ${ }^{71}$ In the Court's words, this "is a statute enacted for a private class of people, those being the owners of, and others dealing with, condominium property."72 Although the case concerned waiver of a statutory provision (discussed in Part IV, below), and not contracting out, it is equally applicable to contracting out. On the basis of the principle in this case, a court would be hard-pressed to find that the Water Act rights allocation framework only concerns private interests in the same manner that the Condominium Act only concerns private interests. As is made abundantly clear by the purposes of the Water Act, ${ }^{73}$ the Act concerns many aspects of a public interest in water, such as the need to manage and conserve water to sustain our environment and the shared responsibility of all residents for the conservation and wise use of water; not merely the regulation of the private use of water.

In conclusion, on the basis of the above, if an industry signatory insisted on exercising Water Act and licence rights over the limitations of the Framework and Industry Agreement, a court might well find for the licensee. In doing so it would find that a licensee cannot legally contract out of statutory water rights and, if the licensee purports to do so, the contracting out would not be enforceable.

\section{ENFORCER OF THE INDUSTRY AgREEMENT}

This section considers who may enforce the Industry Agreement when conceived as a contract, and how enforcement would proceed. These matters are important in two events. First, in the event that an industry signatory reneges on the Industry Agreement and Framework, but does not wage a court challenge as to whether water rights prevail over the Agreement and, second, in the unlikely event that such a challenge is waged and a court finds that the Agreement prevails over water rights. If government may enforce the Agreement it follows that there is more protection for the instream flow in the Athabasca River. It could then act in the public interest to attempt to compel signatories to comply. However, if only the parties to the Agreement may enforce it, then there is less protection as one or more of the parties must come forth to enforce. If no one does, there is no protection for the Athabasca River.

It is basic contract law that a person who is not privy to a contract cannot sue on it. ${ }^{74}$ The industry signatories are the parties to the Industry Agreement. No government agency is party to the Agreement. Accordingly, the government cannot sue on the Agreement.

Could the government be made a party to the Industry Agreement so as to entitle it to sue on it or, better yet, compel enforcement without the need for a lawsuit? On the basis of a strong body of case law it is unlikely that the government could legally enter into such a contract. $^{75}$

R.S.N.W.T. 1988, c. C-15. The Court considered ss. 19(1)(b), 19(1)(d)-(e).

CIBC Mortgage Corp. v. Kilabuk-Bourassa, [1998] N.W.T.R. 21 at para. 9 (S.C.).

Supra note 66 and accompanying text.

See e.g. Dunlop Pneumatic Tire Co. Ltd. v. Selfridge and Company Ltd., [1915] A.C. 847 (H.L.) [Dunlop].

I thank second year University of Calgary law student Robert Black for his excellent research on aspects of this section. 
First, consider the proposal insofar as it varies a legislative scheme. Numerous cases stand for the principle that the Crown cannot legally contract in a manner that could fetter a future exercise of discretion. ${ }^{76}$ Accordingly, if government were made a party to a contract among the oil sands licensees, insofar as the contract would fetter any future exercise of government discretion given by the Water Act, a court should find it to be void. There are many aspects of the Industry Agreement that would, at least impliedly, require such fettering of discretion. For example, the Agreement requires water sharing in certain circumstances that are not authorized by the Water Act. If such sharing were to occur, it would constitute a departure from legal priorities in accordance with FTFR. In such a situation, under the Water Act the government has the right to issue a water management order to administer priorities and rights in accordance with the Act and licences. ${ }^{77}$ The government could not fetter its discretion under a contract by agreeing, whether expressly or impliedly, not to issue a water management order to enforce priorities. It is arguable that government merely being a party to a contracting out of, or waiver of, priorities is an implied fettering of its discretion to enforce them. Therefore, a court should find this aspect of the contract to be void.

What, then, could be included in such a contract? Could, for example, a contract give the government enforcement powers over and above powers conferred by the Water Act? For example, could such a contract give government the right to effectively prohibit withdrawals in excess of cumulatively limited withdrawals where such withdrawals would otherwise be authorized by the industry signatories' licences? The Environment Minister and other statutory delegates get powers through legislation. There is nothing in the Water Act that gives such delegates the right to enforce matters that are not specified under the Act. Nothing in the Water Act, except for the possibility of emergency powers (discussed in Part V, below), would give statutory delegates the required enforcement powers. ${ }^{78}$ Accordingly, such a contract could not contain the kinds of provisions that would give government the power to directly enforce an infraction by an industry signatory.

A leading case is Rederiaktiebolaget Amphitrite v. R., [1921] 3 K.B. 500. The Court found that British authorities' contract to exempt Sweden from a strict naval blockade policy was unenforceable. Justice Rowlatt ruled that it was not competent for the government to fetter its executive discretion in making such an agreement because government "cannot by contract hamper its freedom of action in matters which concern the welfare of the State” (at 503). In Canada, British Columbia (A.G.) v. Esquimalt \& Nanaimo Railway (1949), [1950] 1 D.L.R. 305 (P.C.), suggests that the Crown cannot bind itself in a contract that requires it to enact or promise to keep certain legislation on the statute books. The case concerned an alleged breach of contract by the British Columbia government where the government failed to maintain a tax exemption for a railroad. The Supreme Court of Canada in Pacific National Investments Ltd. v. Victoria (City of), 2000 SCC 64, [2000] 2 S.C.R. 919, found a contract between a municipality and a construction firm to be void where the municipality promised not to use its zoning powers to prevent the firm from moving ahead with certain projects.

77 Supra note 12, s. 97(1)(a). The Water Act enables a Director to issue a water management order in prescribed circumstances.

Although a thorough review of the Water Act, ibid., enforcement and enforcement-like provisions is not provided in this article, note the following. The Water Act's main enforcement or enforcement-like powers are powers related to offences, and water management orders that may be made when no offence has been committed. None of the offence provisions would apply to give government the right to enforce a contract that varies the Water Act's rights scheme. As well, the Act's provisions that authorize a Director to issue a water management order when no offence has been committed, except for the possibility of a water management order issued after the declaration of an emergency (discussed in Part V, below), would not apply to infractions of an Industry Agreement. Section 97 of the Act sets out the specific circumstances in which a Director under the Water Act may issue a water management order. Although s. 97(1)(h) gives a Director the right to issue a water management order to a licensee when a diversion "caused, causes or may cause a significant adverse effect" on the aquatic environment, this provision only applies to licences issued under the Water Act, and therefore only to post-1999 licences. It would not apply, for example, to Syncrude's and Suncor's licenced 100,000 acre feet per year. 
Finally, is it against public policy for government to enter into a contract that varies a statutory scheme where a statute does not authorize such a variance? Earlier this article set out arguments and observations which concluded that a court might well find that it would be against public policy for the industry signatories to contract out of Water Act entitlements. These arguments are even more compelling when applied to government, the maker of legislation. The Water Act specifically binds the $\mathrm{Crown}^{79}$ and surely it is against public policy for the Crown to contract out of a statutory scheme to which it is bound.

\section{THE ENFORCEABILITY OF THE INDUSTRY AGREEMENT}

\section{INTRODUCTION}

This section considers whether the Industry Agreement itself is enforceable. It first looks at whether it is unenforceable because it offends public policy, and then at whether it is enforceable qua contract. Although this article will not go into great detail, it concludes that a review of the latest Industry Agreement indicates that it likely does not effectively require the signatories to comply with the Framework.

\section{CONSIDERATION}

The Agreement does not appear to be under seal, and so it requires consideration. Consideration must normally be given by the promisee to the promisor in return for the promise.$^{80}$ Monetary consideration or other consideration is not mentioned in the Agreement. Accordingly, the only possible consideration found would be by virtue of mutual promises. At law, mutual promises may constitute consideration if performance of the promises would constitute consideration. ${ }^{81}$ Would performance by one party constitute consideration? Although consideration need not have more than nominal value (for example, a peppercorn), it must have some value. ${ }^{82}$ But what value is it for any of the parties to agree not to, in effect, assert their legal rights to water entitlements? It is not clear whether a court would find consideration to be flowing among the industry signatories.

The fact that consideration does not flow among the industry signatories may not be fatal. This is because "[t]he law does not require that the consideration must flow from the promisee to the promisor, merely that there be consideration flowing from the promisee to someone. ${ }^{, 83}$ Could consideration flow from the industry signatories to Alberta Environment? Alberta Environment certainly relies on the Agreement and benefits from it. Regarding reliance, it continues to grant water rights to new and expanded projects with the understanding that the industry signatories will comply with the Agreement. Regarding benefits, Alberta Environment benefits as a key legislator and water manager relating to instream flows in the Athabasca River. But what consideration flows from the industry signatories to Alberta Environment? Arguably this would be Alberta Environment's reliance

Ibid., s. 4.

G.H. Treitel, The Law of Contract, 4th ed. (London: Stevens \& Sons, 1975) at 46.

Ibid. at 48.

Ibid. at 53.

Bank of Montreal v. Danial and Danial (1983), 46 A.R. 64 at para. 19 (Q.B.). See also Sheckter v. Polonuk, [1992] A.J. No. 974 (C.A.) (QL); Dunlop, supra note 74 at 853. 
on the Framework and Industry Agreement as they now stand, instead of expressly regulating compliance.

\section{CONTRACT REMEDIES - SPECIFIC PERFORMANCE, THE AGREEMENT, AND THE FRAMEWORK}

Assuming the hurdle of consideration could be overcome (which is not certain) the question is, what happens if party A abides by the Agreement, and party B does not? The only way there could be enforcement of the Industry Agreement would be if A sues B. But why, one might ask, would A, a resource company working alongside other resource companies in the oil sands, sue B for non-compliance with the Agreement? Would it not be just as reasonable, at least from an economic point of view, for A to sit back and do nothing, or perhaps even decide that A now has the opportunity to not comply as well, without the sharp sting of negative public reaction, since B was the first to not comply?

Setting this conundrum aside for the moment, consider more closely the contract remedy. Assume that A for some reason decides to sue B on the Agreement. If the environmental goal of the Agreement is the protection of the river, then the only reasonable remedy would be specific performance and an injunction, not damages. Damages would be an inadequate remedy for two reasons. First, it is difficult to ascertain what, if any, damages party A suffers if B reneges on a promise made in the Industry Agreement. Second, even if party A were paid damages, this would not remedy the damage to the river.

Ignoring for the moment the potential ramifications for the river during the time it took to get the action started and heard and an injunction to issue, consider whether specific performance is an adequate remedy. In particular, would an order requiring the parties to abide by the Industry Agreement compel the parties to comply with the Framework? Unfortunately for the river, the likely answer is "no.” This is because the Industry Agreement falls considerably short of a promise by the industry water rights holders to comply with the Framework. Here are some reasons why:

- On the first page of the Industry Agreement, industry agrees to "underlying principles" such as "steward[ing] net instantaneous withdrawals." ${ }^{44}$ Agreeing to underlying principles is not agreeing to do anything. As well, it is uncertain what "stewarding” withdrawals requires.

- Attachment 1 to the Agreement is more certain than simply agreeing to principles, as in it the industry signatories expressly agree to "cumulatively limit withdrawals from the Athabasca River in order to meet withdrawal targets established” by the Framework. ${ }^{85}$ Notwithstanding the initial clarity, there are so many exceptions that, in the end, it is not clear to what extent the Framework will govern industry behavior. Here are some examples: 
- The parties agree that "[i]f companies exceed individual limits ... they must report exceedences to AENV” (Alberta Environment) ${ }^{86}$ One wonders if a court could compel any other action than reporting an exceedence to the government.

- The Agreement recognizes the "overriding need to ensure the safety and physical integrity of operating oil sands equipment and facilities at all times."87 The Agreement contemplates that more water than the cumulative limits may be required for emergencies, potable water needs, and "water systems requirements to maintain operation.” These are very open-ended exceptions to the cumulative withdrawal limitations.

- The Agreement is valid only for the yellow and red flow periods for winter weeks 44-16 (29 October 2008 to 15 April 2009). The Framework’s green, yellow, and red periods apply to each week of the year. ${ }^{88}$ In fact, Alberta Environment issued a yellow zone warning for the Athabasca on 1 May, which is week 18 of the 2009 period. ${ }^{89}$

\section{The Industry AgreEment: CONTRACT LEGAL IsSUES SUMmARY}

In summary, there are many arguments that may reasonably be made concerning the Industry Agreement when conceived as a contracting out of the Water Act, and the rights issued under the Act, that support a conclusion that it does not ensure industry compliance with the Framework. These are:

1. That the Water Act, by implication, prohibits contracting out of licenced water rights.

2. The contracting out may fail because it is not express.

3. The contracting out may fail for being against public policy as, arguably, the water rights framework of the Water Act is public and fundamental law.

4. The contracting out may fail as the Water Act is not designed to regulate private rights only.

5. The contracting out may fail because, arguably, the statutory scheme governing allocation rights in licences was legislated for the public interest.

6. Even if the Agreement were a valid contract, it may only be enforced by the industry signatories and it is not clear that it is in the interest of any of these parties to compel compliance. 
7. The government likely could not legally be made a party to the Agreement.

8. Even if the government could be made a party to the Agreement, the terms would necessarily be limited to ensure that the government was neither fettering its discretion nor going beyond its legislated authority.

9. Specific performance of the contract would not clearly require specific performance of the Framework since the promises in the Industry Agreement fall short of the Framework's requirements.

\section{WAIVER OF WATER ACT RightS}

\section{A. WAIVER OF STATUTORY Rights}

Part III, above, showed how the Industry Agreement, when conceived as a contract, likely is not enforceable or effective so as to ensure that the Framework is adhered to by the industry signatories. This Part considers whether the Industry Agreement is enforceable and effective when conceived as a waiver of Water Act and licence rights.

The law concerning waiver of statutory rights is similar to the law concerning contracting out of statutory rights. As noted earlier, Côté states that "[a]n individual may waive the benefit of a right enacted in his favour ... [b]ut it is not possible to dispense with a statute which has been partially or entirely adopted in the public interest." ${ }^{90}$ Based on the article's discussion of this issue above, it is unlikely that a court would find that the Water Act could be dispensed with as it, at least in part, has been adopted in the public interest.

\section{B. WAS THERE AN EFFECTIVE WAIVER?}

Even if a court found that a person could validly waive Water Act and licence rights, it may be asked whether the industry signatories effectively waived their licence and statutory rights. In other words, is what they did in fact and law a waiver?

In the 1918 Alberta Supreme Court, Appellate Division decision Crump v. McNeill, Hyndman J. explained:

\footnotetext{
Waiver is defined as the act of waiving, or not insisting on some right, claim or privilege; a foregoing or giving up of some advantage, which but for such waiver, the party would have enjoyed; an election to dispense with something of value, the giving up, relinquishing, or surrendering some known right; an intentional relinquishment of a known right, or such conduct as warrants an inference of the relinquishment or waiver of such right; waiver involves both knowledge and intention. ${ }^{91}$
}

Waiver was further clarified in the Saskatchewan Court of Appeal decision Western Canada Investment Co. Ltd. v. McDiarmid, which established that for waiver to exist “[t]here must be a knowledge of the existence of the right or privilege relinquished and of the 
possessor's right to enjoy it, and there must be a clear intention of foregoing the exercise of such right." 92 A version of this test has since been adopted by the Supreme Court of Canada in Saskatchewan River Bungalows Ltd. v. Maritime Life Assurance Co., where the Court states that

[w] aiver will be found only where the evidence demonstrates that the party waiving had (1) a full knowledge of rights; and (2) an unequivocal and conscious intention to abandon them. The creation of such a stringent test is justified since no consideration moves from the party in whose favour a waiver operates. An overly broad interpretation of waiver would undermine the requirement of contractual consideration. ${ }^{93}$

Recalling the earlier discussion of the comparable requirement for contracting out, it is unlikely that the industry signatories effectively waived Water Act and licence rights. The Industry Agreement does not even mention the Water Act or licence rights. Consequently, it is unlikely that the Industry Agreement itself constitutes an unequivocal and conscious intention to abandon Water Act and licence rights. As set out in Part III.D, below, some provisions of the Industry Agreement call into question whether the signatories agree to be bound by the Framework.

\section{WAIVER AND PROMISSORY ESTOPPEL}

Assuming, notwithstanding the above discussion, a court found that the industry signatories did effectively waive rights under the Water Act and their licences, a question may be raised as to who may enforce this waiver. In particular, would Alberta Environment be able to enforce the waiver? Most Canadian scholars on the subject suggest that waiver has been subsumed by promissory estoppel. ${ }^{94}$ Accordingly, promissory estoppel must be investigated to ascertain whether Alberta Environment could enforce the waiver.

The doctrine of promissory estoppel first emerged in Central London Property Trust Ltd. $v$. High Trees House Ltd. ${ }^{95}$ John McCamus explains the concept of promissory estoppel that emerges from High Trees as follows:

[W]here one has given, albeit gratuitously, a promise that was intended to be binding and intended to be acted upon and which was in fact acted upon, the promise should be considered to be binding.

the role of promissory estoppel ... [is] restricted to preventing parties from insisting upon their strict legal rights in situations where it would be unjust to allow actions to enforce them. ${ }^{96}$

These quotes reflect the maxim that estoppel may be raised as a shield but not a sword. For example, if a bank sues a debtor, the debtor may argue that the bank is estopped from

(1922), 15 Sask. L.R. 142 at 146 (C.A.).

[1994] 2 S.C.R. 490 at 504.

See Angela Swan, Canadian Contract Law, 2d ed. (Markham, Ont.: LexisNexis, 2009); John D. McCamus, The Law of Contracts (Toronto: Irwin Law, 2005).

[1947] K.B. 130 [High Trees].

McCamus, supra note 94 at 279-81. 
demanding payment of the debt because of some prior representation that the bank made to the debtor. But the debtor cannot sue the bank on the basis of the prior representation. That would be using estoppel as a sword.

It is tempting to try to apply estoppel so that an industry signatory would be prevented estopped - from insisting on its entire water allocation where the Framework and Industry Agreement would limit the allocation. But on analysis it becomes clear that such an estoppel cannot arise. Consider an example. Suppose industry signatory A reneges on its promise in the Industry Agreement and diverts its whole water entitlement under its licence at a time when the Framework would limit the withdrawal. Then suppose that industry signatory B sues A. Since estoppel may be raised as a shield and not as a sword, there is no estoppel that $\mathrm{B}$ (or any one else) may raise in this situation. Trying to do so would turn estoppel into a sword.

Estoppel can be confusing because, although the shield approach prevails in Canada, the U.S. and Australia have invoked promissory estoppel as a cause of action since the 1980s.

\section{The U.S. Restatement (Second) of the Law of Contracts states that}

[a] promise which the promisor should reasonably expect to induce action or forbearance on the part of the promisee or a third person and which does induce such action or forbearance is binding if injustice can be avoided only by enforcement of the promise. The remedy granted for breach may be limited as justice requires. $^{97}$

Similarly, in Waltons Stores (Interstate) Ltd. v. Maher, ${ }^{98}$ the High Court of Australia allowed estoppel to be used as a sword.

Although promissory estoppel is still confined to its shield position in Canada, there has been a nod, albeit in obiter, to the sword approach. ${ }^{99}$ However, until Canadian courts fully adopt estoppel as a sword, it is difficult to imagine a fact situation involving non-compliance with the Industry Agreement where promissory estoppel could be raised to address the issue.

As a last note on this subject, even if Canadian courts determined that promissory estoppel could be used as a sword, it is not clear that using it would lead to compliance with the Framework. In Canadian Contract Law, Angela Swan discusses an important rule from Waltons Stores. ${ }^{100}$ She states that the party relying on a statement or promise of another must

Restatement (Second) of the Law of Contracts § 90(1) (1979).

[1988] HCA 7, 164 C.L.R. 387 [Waltons Stores]. The facts were: Waltons, in negotiating to lease property from Mr. Maher, indicated that the current building would have to be torn down and new one built, to Waltons' specifications, immediately in order to meet the projected date of occupancy. A draft lease was prepared, with amendments, and, believing that execution of the lease was a mere formality, Maher commenced demolition and construction. Forty percent of the project had been completed when Waltons informed Maher that they would not be proceeding with the transaction. The Court found that Waltons was estopped from not proceeding.

Waltons Stores, ibid., was distinguished but not rejected in M.(N.) v. A.(A.T.), 2003 BCCA 297, 13 B.C.L.R. (4th) 73. The Ontario Court of Appeal has indicated support for the American doctrine in obiter: see Francis v. Canadian Imperial Bank of Commerce (1994), 21 O.R. (3d) 75 at 84 (C.A.); Techform Products Ltd. v. Wolda (2001), 56 O.R. (3d) 1 (C.A.). See also Sail Labrador Ltd. v. Challenge One (The), [1999] 1 S.C.R. 265 at para. 85.

Supra note 94. 
be able to show "actual reliance as a matter of fact." ${ }^{101}$ How would this be applied if B, a compliant industry signatory, sued $\mathrm{A}$, a non-compliant signatory? It is not clear what actions B could point to that demonstrate reliance in fact on the Industry Agreement, or an industry signatory's compliance with it.

\section{THE INDUSTRY AgREEMENT: WAIVER LEgAL ISSUES SUMMARY}

In summary, there are many arguments regarding the Industry Agreement, when conceived as a waiver of Water Act and licenced rights issued under the Act, that reasonably support a conclusion that the Agreement does not offer much to ensure industry compliance with the Framework. These are:

1. The waiver argument may fail for being against public policy because the Water Act is not designed only to regulate private rights.

2. It is not clear whether the industry signatories clearly and indisputably waived their Water Act and licence rights in the Industry Agreement.

3. The waiver would fail because the industry signatories could not be compelled to comply with the waiver through promissory estoppel. In Canada, promissory estoppel may be raised as a shield only, and not as a sword.

4. Even if courts allowed promissory estoppel to be used as a sword, it is unlikely that it could be successfully wielded to require compliance with the Industry Agreement.

\section{REGULATORY BACKSTOPS}

\section{A. REgULATORY BACKSTOPS AND THE FRAMEWORK}

The Framework uses the term "backstop" or "regulatory backstop" in two ways. The first means the dates on which the regulators (DFO and Alberta Environment) will make decisions regarding issues identified in the Phase 1 and 2 processes if stakeholders cannot agree on a path forward by a stated deadline date. ${ }^{102}$ The second is the more common use of the term. The term "regulatory backstop" typically means regulatory measures that a regulator will impose if non-regulatory expectations are not met. For example, a government may allow industry to reduce polluting emissions on a voluntary basis with the understanding that if the voluntary approach is not successful, the government will regulate a reduction.

The two regulatory backstops that the Framework briefly discusses are the imposition of conditions on Water Act licences and the use of federal Fisheries Act enforcement provisions. ${ }^{103}$ This Part discusses both of these potential regulatory backstops and evaluates their adequacy should the Industry Agreement be unenforceable or otherwise prove lacking. The Part concludes that neither regulatory backstop will clearly enable the regulators to 
protect the IFNs of the Athabasca River in accordance with the Framework. The Part also discusses Water Act emergency powers as Alberta Environment Minister Renner recently discussed them in the context of Phase 2 of the Framework. ${ }^{104}$ The Part concludes that Water Act emergency powers do not provide a wholly adequate regulatory backstop.

\section{B. CONDITIONS ON LICENCES}

Alberta Environment's website has an approval viewer function where the public can view select water licences and other approvals. ${ }^{105}$ However, not all documentation relevant to the water licences, especially more senior licences, is available on the website. Based on personal experience usually only the most recent compilation of a licence is available, and often not the original licence. However, copies of Suncor's and Syncrude's earlier diversion authorizations that are not available on the website were acquired for the purposes of this article. Acknowledging the limitations regarding documentation, this section considers conditions relevant to IFNs on the industry licences for diversions from the Athabasca River for oil sands projects to ascertain the extent to which government enforcement of licence conditions would constitute an effective regulatory backstop.

A review of all available industry water licences relating to Athabasca oil sands projects revealed that the most recent water licences contain conditions that clearly require compliance with the Framework. For example, Imperial Oil Resources Ventures Ltd.'s 2005 licence, which ranges from a 56,000,000 $\mathrm{m}^{3}$ yearly water diversion right in the first stage of the company's oils sands projects to $99,000,000 \mathrm{~m}^{3}$ each year in the fifth stage, contains a condition that reads " $[\mathrm{t}]$ he Licensee shall comply with the Water Management Framework: Instream Flow Needs and Water Management System for the Lower Athabasca River (2007), as amended."106 The licence has a priority date of 2005 and an issuance date of 2007. The two years between the priority date and issuance date may be accounted for since the Water Act establishes priority as of the date of the completed application. ${ }^{107}$ The Framework was developed between the date of the application and the issuance date.

Things become less clear regarding licences more senior than 2005. For example, the Canadian Natural Resources Ltd. licence, with a priority date of 2002 and issuance date of 2004, contains the following conditions:

8. The Director reserves the right to establish instream flow needs (IFN) or other water conservation objectives governing

(a) the rate of diversion; and

(b) the timing;

Healing, supra note 29.

Government of Alberta, “Authorization/approval viewer,” online: Alberta Environment <http:// environment.alberta.ca/01519.html>.

Alberta Environment, Licence No. 00222199-00-00, Athabasca River, issued to Imperial Oil Resources Ventures Ltd. (19 December 2007) at 4, online: Alberta Environment <http://envext02.env.gov.ab.ca/ pdf/00222199-00-00.pdf>.

Supra note 12, s. 29. 
of diversions from the Athabasca River downstream of Fort McMurray, effective in accordance with written notice to the licensee.

9. To protect the aquatic environment, the licensee shall reduce the maximum rate of water diversion or cease diverting when ordered in writing by the Director.

10. This licence is based on knowledge available at the time of issue, and therefore the Director reserves the right to:

(a) amend this licence to reduce the quantity of water diversion;

(b) amend this licence to reduce the maximum rate of water diversion;

if, in the Director's opinion, an adverse effect has occurred, is occurring or may occur due to the diversion of water under this licence on:

(e) the Athabasca River

(g) instream flow needs;

(h) instream objectives; or

(i) the aquatic environment;

and the adverse effect has not been or cannot be remedied to the satisfaction of the Director. ${ }^{108}$

Although the provision appears strong at first blush, on analysis it likely would not prove to be an effective regulatory backstop to the Framework and Industry Agreement. First, it does not require compliance with the Framework. For example, the licensee is not required to limit withdrawals unless the Director takes various actions, as described in the provision, and it does not require cumulative limitations on withdrawals. FTFR applies as usual. Second, before making changes to the licence to address IFNs, the Director must reasonably be of the opinion that an adverse effect on the Athabasca River or IFNs is due to withdrawals under this licence. ${ }^{109}$ Given that cumulative withdrawals by licensees, perhaps in conjunction with natural low flow conditions, in all likelihood would have caused the adverse effect, the Director might have great difficulty forming a reasonable opinion that withdrawals in respect of this particular licence caused the adverse effect. Resources Ltd. (6 April 2004) at 2-3, online: Alberta Environment <http://envext02.env.gov.ab. ca/pdf/00186921-00-00.pdf $>$. 
As we go back further in time to the first licences issued for the Athabasca in connection with oil sands projects, further uncertainty arises. These are Suncor's 1965 priority licence for 25,000 acre feet, its 1979 priority licence for 23,500 acre feet, ${ }^{110}$ and Syncrude's 1973 priority licence for 50,000 acre feet. ${ }^{111}$ To understand the issues concerning these licences, a distinction must be made between an "interim licence" and a final, or regular licence. Both Suncor's and Syncrude’s licences were issued under the Water Resources Act. Under this Act, where an applicant for a licence was required to complete works the Minister would issue an interim licence. ${ }^{112}$ When the works were completed the Act contemplated that the interim licensee apply for, and be issued, a regular licence. ${ }^{113}$

Both Suncor and Syncrude were originally granted interim licences. Only a copy of the original Syncrude interim licence was obtained. ${ }^{114}$ The original Syncrude interim licence did not include any terms that would specifically allow for adjustments to address IFN. Both the Suncor and the Syncrude original interim licences were "updated and reissued" in 1986 and 1987 respectively. The explanation given on the licences was:

This updated and re-issued Interim Licence particularizes the rights, privileges and obligations embodied in and associated with the original Interim Licence as numbered above, or with any other form of authorization or approval issued in connection with the project identified herein under any former applicable Act or regulation, and updates same to conform to and comply with the current Act, regulations and standards. ${ }^{115}$

In the process of updating and reissuing the original interim licences, conditions were added, including one that enables the Water Controller to "designate a minimum residual flow rate immediately downstream of the point of diversion and the licensee shall be required to cease or reduce any further diversion during periods when the residual flow falls below the rate designated"116 (the IFN condition). Although the IFN condition would not enable government to enforce the Framework per se (for example, it would not require cumulatively limited withdrawals), if the condition is enforceable, government could use it to require Suncor and Syncrude to reduce withdrawals to protect IFNs.

Interestingly, the conditions, including the IFN condition, were added to the Suncor and Syncrude interim licences on the same day that they were issued regular licences. ${ }^{117}$ Assuming that the IFN condition was imposed and not negotiated with Syncrude and

$\begin{array}{ll}110 & \text { Supra note } 25 \text { at } 2 . \\ 111 & \text { Supra note } 26 \text { at } 2 .\end{array}$

112 Water Resources Act, supra note 13, s. 18(1).

113 The term of an interim licence was only one year, though the Water Resources Act, ibid., enabled the Minister to grant extensions, but only if the Minister was satisfied that the "completion of the works has been retarded by physical conditions over which the holder of the interim licence has no control” (s. 18(2)). Interestingly, numerous licences on the Alberta Environment approval viewer website are still interim licences.

Alberta Water Resources Office, Interim Licence No. 7695, Athabasca River, issued to Syncrude Canada Ltd. (21 February 1974). The licence was for 1,000 acre feet of water annually.

Syncrude Licence, supra note 26 at 2; Suncor Licence, supra note 25 at 5.

Syncrude Licence, ibid. at 3; Suncor Licence, ibid. at 5.

Syncrude's finalized licence was issued on 20 October 1986. Although I was not able to obtain a copy of the actual licence, the Updated and Reissued Interim (Syncrude Licence, ibid.) refers to the actual licence. Suncor's licence was issued on 8 June 1987. 
Suncor, ${ }^{118}$ the question is, can the government enforce it? It is impossible to canvass all arguments for and against in this article. However, it will be noted that if government chose to enforce the IFN condition, Syncrude and/or Suncor might have arguments to challenge the action. One ground could be that although the Water Resources Act specifically authorized substantive amendments to licences, by Cabinet Order with the agreement of both the Minister and the licensee, ${ }^{119}$ it was silent as to amendments to interim licences. By application of the principle expressio unius est exclusio alterus, the express authorization of amendments to licences implies that only licences, and not interim licences, may be substantively amended. ${ }^{120}$ This argument could be countered, as the Water Resources Act authorized interim licences to be issued "subject to any conditions the Minister considers necessary." 121 The original Syncrude interim licence enables "modification to ensure the most beneficial use of the water in the public interest and more particularly to ensure preservation of the rights of other water users." ${ }^{\text {"22 }}$ But it also states that the "the rights and privileges hereby granted can only be ... modified with the approval of the Controller of Water Resources and are subject to ... modification as provided in the Water Resources Act." ${ }^{\text {123 }}$ A response to this counter-argument is that the IFN condition does not qualify as a condition that "ensure[s] the most beneficial use of the water ... particularly to ensure ... the rights of other [users]." "124 As well, as noted above, the Water Resources Act contained no provisions regarding modification of an interim licence.

Also of interest, the Water Act purports to legitimize a "reissued interim licence" by deeming it to be "a valid and subsisting interim licence under the Water Resources Act."125 This legitimizing provision would not, in all likelihood, apply so as to validate the IFN condition carried over from the reissued and updated interim licences of Suncor and Syncrude to their finalized licences. In the statutory context it is apparent that "reissued interim licence" means a reissued and interim licence that still exists and not one that was replaced by a finalized licence prior to the Water Act coming into effect. ${ }^{126}$ Once a finalized licence issues, that licence governs water rights, not the interim licence. The finalized licence replaces the interim licence.

My personal investigation into this matter has not clarified whether this condition was imposed. My water law research over the last eight years has involved reviewing numerous licences available on the Alberta Environment website, especially in the South Saskatchewan River Basin. These reviews indicate that it was common for older water diversion authorizations to be updated and reissued where conditions are added on the reissuance. Water Resources Act, supra note 13, s. 14.

Interestingly, the Water Resources Act, ibid., specifically enabled the Minister, once works described in an interim licence were satisfactorily constructed, to issue a licence to the applicant "for the quantity of water to which he is entitled, subject to any conditions the Minister prescribes" (s. 33(3)). This makes it clear that the Minister could have added conditions to Suncor's and Syncrude's final licences that were not in the Suncor and Syncrude interim licences. However, the Minister chose to amend the interim licences. Perhaps the Minister took this course in light of the statutory requirement that licences be issued for the entitled quantity of water, which suggests that conditions could not be added that would alter that quantity. An IFN condition would alter the quantity if the flow in the diversion source was lower than prescribed in the licence.

Ibid., s. 18(1).

Syncrude Licence, supra note 26 at 3.

Ibid. at 4 .

Ibid. at 3.

Supra note 12, s. 18(7)(a).

As well, a court would likely interpret s. 18(7) very narrowly as it can have the effect of impacting vested rights. Hence this provision probably would not apply to the Suncor and Syncrude licences. 
To conclude this discussion on conditions, although Alberta Environment has some regulatory backstop power by virtue of licence conditions, this power is clear only with respect to the most recent licences. It becomes less clear with older licences, and with respect to the oldest licences the power is questionable. Hence, enforcing licence conditions is not a consistently dependable regulatory backstop.

\section{FISHERIES ACT REQUIREMENTS}

The Framework states that when the yellow or red zone is triggered, withdrawals may result in a federal Fisheries Act offence unless authorized under s. 35(2) of that Act. ${ }^{127}$ Section 35, briefly discussed above, provides:

(1) No person shall carry on any work or undertaking that results in the harmful alteration, disruption or destruction of fish habitat.

(2) No person contravenes subsection (1) by causing the alteration, disruption or destruction of fish habitat by any means or under any conditions authorized by the Minister or under regulations made by the Governor in Council under this Act. ${ }^{128}$

Is s. 35 of the Fisheries Act an adequate regulatory backstop for the Framework? The answer, unfortunately, is probably not for several reasons.

First, the Framework assumes that water withdrawals under provincial water licences are works or undertakings. Although there is case law stating that the complete drainage or destruction of water courses are works or undertakings, ${ }^{129}$ there is no case that indisputably determines whether mere water withdrawals are works or undertakings. If an industry signatory contested whether a water withdrawal pursuant to a provincial water licence is a work or undertaking for the purposes of s. 35 of the Fisheries Act, the matter might well end up in court. Even if a court ultimately decided that a withdrawal is a work or undertaking, unless the government was able to secure an injunction in the meantime, which would not be a certainty, fish habitat could be seriously impaired. ${ }^{130}$

Second, s. 35 appears to require that a harmful alteration, disturbance, or destruction (HADD) of fish habitat be caused by a single work or undertaking. ${ }^{131}$ This poses a problem for the DFO, as it may not be able to establish that an offence was committed by any particular water licensee. It would likely be the case that industry water withdrawals cumulatively resulted in a HADD - perhaps with the help of natural low flows - with no single withdrawal causing it. The federal government could prosecute the last withdrawal

Framework, supra note 11 at 10, 19.

Supra note 15.

For example, in Prairie Acid Rain Coalition v. Canada (Minister of Fisheries and Oceans), 2006 FCA 31, [2006] 3 F.C.R. 610, TrueNorth Energy had received authorization under the Alberta Water Act for drainage required for the proposed Fort Hills Oil Sands Project. The Federal Court of Appeal noted that TrueNorth also required authorization from the DFO under s. 35(2) of the Fisheries Act, ibid., since the project involved the destruction of Fort Creek, a fish-bearing watercourse (at paras. 32-34).

In my view, a court would likely find that a water withdrawal under a provincial water licence is a work or undertaking. However, it is beyond the scope of this article to argue the point.

If there is an ambiguity, a court should apply the presumption against penal consequences to interpret the provision in favour of the accused. 
that resulted in the HADD, but that licensee might contest the charge on the grounds that its withdrawal only resulted in the HADD when taken in conjunction with other withdrawals. If the federal government charged all licensees whose withdrawals partially resulted in a HADD, the licensees could argue that s. 35 does not permit the dissecting of the offence into many pieces. Again, the matter could well end up in court, while IFNs would suffer.

Third, the Framework specifically states that withdrawals made under pre-1977 Suncor and Syncrude licences will not require a Fisheries Act authorization. ${ }^{132}$ This exemption is made on the grounds that doing so would involve a retroactive application of the s. 35 HADD provisions, which came into effect in $1977 .{ }^{133}$ Although this interpretation is almost certainly wrong, it might take a court to prove the error. ${ }^{134}$ In the meantime, it could be very difficult for the DFO to prove a Fisheries Act s. 35(1) offence if a HADD resulted from cumulative withdrawals that included withdrawals by Suncor or Syncrude. The Crown would have to subtract their withdrawals from the cumulative amount and still have enough evidence to justifiably maintain that the HADD still would have occurred in order to require licensees other than Suncor and Syncrude to obtain an authorization under s. 35(2), or to prosecute them for the lack of authorization.

Regarding the Framework's exemption for pre-1977 water licensees, it is of interest that in 2008 the DFO issued a Department Position Statement, which states:

The habitat protection provisions of the Fisheries Act apply to the ongoing operation, modification, maintenance or other works and undertakings associated with an existing facility /structure in or near fishbearing waters, even if the facility or structure was constructed prior to the enactment of those provisions. ${ }^{135}$

In light of this, assuming that a water withdrawal is a work or undertaking, it is incongruous that the Framework exempts withdrawals under pre-1977 water licences from the application of s. 35 of the Fisheries Act.

Framework, supra note 11 at 19. Specifically, the Framework states:

Since Syncrude and Suncor obtained licences to withdraw water from the Athabasca River prior to the implementation of the habitat provisions of the Fisheries Act they did not require Fisheries Act authorizations. However, any future change in operations that results in increased impacts on fish and fish habitat is subject to current legislation and may result in the requirement of a Fisheries Act authorization.

These licences amount to 75,000 acre feet of water per year: see Suncor Licence, supra note 25; Syncrude Licence, supra note 26.

133 An Act to Amend the Fisheries Act and to amend the Criminal Code in consequence thereof, S.C. 197677, c. 35, s. 5.

134 Applying the HADD provisions to current withdrawals would either be a prospective or retrospective application of the 1977 provisions and not a retroactive application in the sense that "retrospective" and "retroactive" are applied by the Supreme Court of Canada in Dikranian v. Quebec (Attorney General), 2005 SCC 73,[2005] 3 S.C.R. 530. A retroactive application of law changes the law in the past, a retrospective application merely adds new consequences to a past event or state of affairs. A prospective application applies only to the future. The HADD provisions do not change the legality of any pre-1977 withdrawals (a retroactive application); they only apply to post-1977 withdrawals (a retrospective or prospective application). Although there is a presumption that a legislature does not intend legislation to be applied retroactively, there is a no presumption that a legislature does not intend a retrospective or prospective application (at paras. 31-36). See also Ruth Sullivan, ed., Sullivan and Driedger on the Construction of Statutes, 4th ed. (Markham, Ont.: Butterworths, 2002) at 553-64.

135 Fisheries and Oceans Canada, Application of the Habitat Protection Provisions of the Fisheries Act to Existing Facilities and Structures (Ottawa: Communications Branch, Fisheries and Oceans Canada, 2007) at 1. 
Finally, s. 35 of the Fisheries Act is not an effective regulatory backstop since the federal government has the discretion to authorize a HADD under s. 35(2) of the Act, thus allowing IFNs to be compromised.

\title{
D. Water Act Emergency PoWers
}

The Calgary Herald recently published the following, quoting Alberta Environment Minister Renner in respect to enforcement of Phase 2 of the Framework:

\begin{abstract}
"the reason we implemented Phase 2 of [the Framework] is to ensure we have as rigid a regulatory regime in place that is necessary to protect not only the users of the river, but the ecosystem as well as the human population...." [t]he ministry has "almost unlimited powers" under the Alberta Water Act emergency provisions to protect rivers during severe drought. ${ }^{136}$
\end{abstract}

This section of the article provides numerous reasons why Water Act emergency powers are not adequate to ensure enforcement of the Framework or protection of IFNs. However, before presenting them, a comment is made regarding the Minister's statement.

The purpose of the Framework is to compel industry water users to cumulatively limit withdrawals to maintain IFNs. The Framework defines "Instream Flow Needs/Instream Needs" as "the amount of water, flow rate, water level, or water quality that is required in a river or other body of water to sustain a healthy aquatic ecosystem."137 This amount of water, flow rate, and water level will invariably be a greater amount of water than is present during "severe drought." The Framework is meant to be preventative; it is meant to curb withdrawals before IFNs are compromised. Accordingly, even if Water Act emergency powers could be used in a severe drought condition, as the Minister states, it does not follow that they could be used to maintain IFNs in accordance with the Framework.

Sections 105 and 107 of the Water Act set out government emergency powers. Section 105 of the Water Act sets out emergency powers of an inspector, investigator, or a Director, and s. 107 sets out emergency powers of the Lieutenant Governor in Council (Cabinet). The provisions read:

105(1) If an inspector or investigator or the Director is of the opinion that an activity, diversion of water or operation of a works

(a) occurred, occurs or may occur, and

(b) caused, causes or may cause an immediate and significant adverse effect on the aquatic environment, human health, property or public safety,

the inspector, investigator or Director may take any emergency measures that the inspector, investigator or Director considers necessary to prevent immediate and significant damage to the aquatic environment, human health, property or public safety. 
(2) Subsection (1) applies whether or not the activity, diversion of water or operation is authorized by an approval, licence or registration and whether or not the approval holder, licensee or traditional agriculture user is or was in compliance with the approval, licence, registration or this Act.

107(1) The Lieutenant Governor in Council may, when satisfied that an emergency related to water exists or may exist, declare an emergency relating to all or any part of Alberta.

(2) Notwithstanding anything in this Act or any approval, preliminary certificate, licence or registration under this Act, if an emergency has been declared under subsection (1), the Director may issue a water management order to any person

(a) suspending the operation of all or part of any approval, preliminary certificate, licence or registration,

(b) suspending a diversion of water,

(c) designating the purposes for which, and the volumes in which, water may be diverted or used

with respect to the area of the Province affected by the declaration.

(3) Licensees or registrants affected by a declaration under subsection (1) may be entitled to compensation for any losses incurred as a result of the order in the manner and amount that the Lieutenant Governor in Council considers appropriate. ${ }^{138}$

First, consider s. 105 emergency powers of an inspector, investigator, or Director. There are many aspects of this section that would make it non-effective as a regulatory backstop to the Framework and Industry Agreement. Note that s. 105(1) requires that a diversion of water or operation of works must cause the emergency in order for an emergency to be declared. This requirement poses four problems to the idea of these emergency provisions being seen as constituting a regulatory backstop to the Framework and Industry Agreement. First, low flows are often naturally occurring. Although industry withdrawals may exacerbate the situation, where low flows are naturally occurring it may be argued that they are not caused by industry. Accordingly, an inspector, investigator, or Director would have difficulty suspending industry water licences. Second, even if the statutory designate could justify a claim that industry withdrawals are a cause of low flows, it does not follow that government could point to any particular industry player as the cause. ${ }^{139}$ Third, it is hard to see how the powers could be used as a regulatory backstop to enforce the cumulative withdrawal limitations of the Framework. This is because it would be open to a senior licensee to argue that it has the right to withdraw in accordance with FTFR, and that only junior licensees should be cut off. Junior licensees in turn could argue that the more senior licensees, and not the juniors, are the cause of the low flows. Fourth, s. 105(1) limits the powers of an

139 The problem is comparable to the one for the DFO described earlier in this Part of the article if it attempted to enforce s. 35 of the Fisheries Act. 
inspector, investigator, or a Director to what is required to "prevent immediate and significant damage to the aquatic environment." ${ }^{140}$ As previously discussed, the main purpose of the Framework is to limit withdrawals to avoid depletions below the amount of water needed to be present to sustain a healthy aquatic ecosystem. Section 105 is an ineffective regulatory backstop to the Framework as it would not authorize action while there is still a healthy aquatic ecosystem to prevent or limit withdrawals in accordance with the Framework since there would not yet be an emergency. There is a considerable difference between a healthy aquatic ecosystem and "immediate and significant damage to the aquatic environment.”

Now consider s. 107, Cabinet powers. Section 107 powers are much broader than those set out in s. 105. They enable Cabinet, "when satisfied that an emergency related to water exists or may exist, [to] declare an emergency relating to all or any part of Alberta.” Courts tend to confer considerable deference on Cabinet in its exercise of statutory powers insofar as the powers are of a purely legislative nature (for example, fully discretionary and exercisable by Order in Council). ${ }^{141}$ However, where an emergency provision contains statutory limitations or pre-conditions on the exercise of powers, in carrying out conditions or acting in respect of limitations Cabinet carries out an administrative function and must act within the ambit of the statutory authority. ${ }^{142}$

As with s. 105, there are a number of problems with s. 107 that render it a less than effective regulatory backstop to the Framework or Industry Agreement. The first relates to the fact that before Cabinet may exercise powers under s. 107 a pre-condition must be met. Namely, Cabinet must be satisfied that there is or may be "an emergency related to water." The Alberta Court of Queen's Bench decision in Alberta Teachers' Association v. Alberta states that in making its determination that a statutory condition precedent exists, Cabinet cannot exercise this discretion arbitrarily. Its “opinion should be informed and reasonable, not whimsical, speculative or political." 143 Given this level of court scrutiny on judicial

$140 \quad$ Water Act, supra note 12.

141 See R. v. Thorne's Hardware Ltd., [1983] 1 S.C.R. 106. See also Eisenhawer v. British Columbia (Attorney General) (1999), 30 C.E.L.R. (N.S.) 35 (B.C.S.C.).

142 Attorney General of Canada v. Inuit Tapirisat of Canada, [1980] 2 S.C.R. 735 at 752 where Estey J. states:

[T]he essence of the principle of law here operating is simply that in the exercise of a statutory power the Governor in Council, like any other person or group of persons, must keep within the law as laid down by Parliament or the Legislature. Failure to do so will call into action the supervising function of the superior court whose responsibility is to enforce the law, that is to ensure that such actions as may be authorized by statute shall be carried out in accordance with its terms, or that a public authority shall not fail to respond to a duty assigned to it by statute.

This principle was applied in Gulf Canada Resources Ltd. v. Alberta (Minister of Resource Development), 2001 ABQB 286, 285 A.R. 307.

1432002 ABQB 240, 310 A.R. 89 at para. 56. This case considered a Cabinet determination that, in its opinion, there was "an emergency causing, or which is likely to cause, unreasonable hardship to third parties” under s. 112 of the Alberta Labour Relations Code, R.S.A. 2000, c. L-1 (at para. 17). The Court found that Cabinet's determination in this case was without jurisdiction. Chief Justice Wachowich states at para. 10 that

when construing a statutory provision relating to the hardships caused by a strike, it must be borne in mind that the very purpose of a strike is to cause some hardship in order to raise the profile of the issues being contested, and to pressure the other side into making concessions. If a strike did not cause some degree of hardship it would be pointless. That is why the hardship suffered must be unreasonable before the Government can order teachers back to work, and that means there must [be] some imminence and inevitability before any hardship can be considered unreasonable. After only one or two days of strike it cannot be said, with any air of reality, that the likely hardship, at that point, is unreasonable. 
review, what would constitute an emergency related to water? Case law indicates that an emergency exists only in extreme situations that are clearly unforeseen. ${ }^{144}$ It is highly unlikely, for example, that flows dipping into the yellow zone, as determined by the Framework, would reasonably constitute an "extreme situation" or that they were "sudden" and "unforeseeable." Accordingly, it is unlikely that, in itself, an industry signatory's noncompliance with the Framework and Industry Agreement in such a situation would reasonably constitute an emergency related to water.

Second, the Supreme Court of Canada has indicated that emergency action may only be taken as long as the emergency actually exists. ${ }^{145}$ Based on this decision, although a Cabinet declaration of an emergency related to water might be justified if flows suddenly and unexpectedly dove into the red zone, emergency action would be permitted only as long as the emergency existed. What this length of time would be is hard to say, but arguably the emergency would cease once flows entered the yellow zone.

Third, it is difficult to see how emergency powers generally could be exercised to enforce the Framework and Industry Agreement. Again, the actions described in these documents are intended to avoid getting into a situation where flows fall below IFNs. As noted earlier, flows at this stage will be considerably higher than at an emergency stage.

In summary, Cabinet emergency powers are not an effective regulatory backstop to the Framework and Industry Agreement. The Framework and Industry Agreement require water management actions in the green, yellow, and red zones. Except for sudden, unexpected drops into the red zone, such management would not occur in an emergency situation and, accordingly, Cabinet would not have reasonable grounds to declare an emergency. Even where Cabinet may reasonably declare an emergency, a declaration should only be effective for the length of the emergency.

\section{A PATH FORWARD}

If they realized their promise the Framework and the Industry Agreement would be novel and innovative ways to protect IFNs in a watershed under increasing pressure, despite the shortcomings of the prevailing water legislative and water rights framework. Unfortunately, the Framework and Industry Agreement, as they stand, do not meet this promise.

This article has argued that the Industry Agreement could be ineffective on a number of fronts. Arguably, a court would find that it is not enforceable as a contracting out or waiver of a legislated water rights framework. Enforcement of the Agreement raises issues of timing and appropriateness of remedy. It is doubtful that the government could become a party to

For example, in Kuypers v. Langley (Township of) (1992), 87 D.L.R. (4th) 303 (B.C.S.C.), the defendant township declared a state of emergency with regard to unprovoked attacks by "dangerous dogs." In exercising emergency power it passed a bylaw allowing for the seizure, impoundment, and possible destruction of "dangerous dogs" that had no expiry. Justice Hogarth, in determining whether an emergency actually existed, used the Shorter Oxford English Dictionary definition of emergency: "the sudden or unexpected occurrence of a state of things" (at 309). Since there was no evidence that the matter arose suddenly or without expectation, Hogarth J. found that there was no emergency.

145 Dupond v. Montreal (City of), [1978] 2 S.C.R. 770 at 795, where the Court stated that "by their very nature exceptional emergency measures cannot be permanent." 
the Agreement in a manner effective to address enforcement issues. The Agreement itself does not provide protection that would ensure the maintenance of IFNs. There does not appear to be an effective regulatory backstop.

But all is not bleak. There are a number of avenues that government and industry could take to render the Framework and Industry Agreement effective and enforceable.

One avenue involves many steps. The first is to revise the Industry Agreement so that it is clear and certain, made for valuable consideration, effectively requires compliance with the Framework, and so that it expressly acknowledges that it constitutes a contracting out and waiver of statutory and licence rights. The second step is that the provincial government must be made a party to the Agreement, and the Agreement must give government effective enforcement powers without the need for court action. The third is that the Water Act must be amended to authorize contracting out and waiver in appropriate situations, and to authorize the provincial government to enter and enforce contracting out and waiver agreements. Obviously the wording of such amendments is critical to ensure that contracting out and waiver are only permissible in situations that meet the purposes of the Water Act and where both public and private interests are respected. Although this course seems cumbersome, it provides a mechanism for voluntary, but enforceable, contracting out or waiver of an otherwise sometimes intractable, and in some ways antiquated, legislated water rights framework that by itself cannot meet modern water management challenges.

Another, more simple, avenue would be for the industry oil sands licensees whose licences do not require compliance with the Framework to voluntarily request amendments to their licences to add conditions that clearly require the licensees to comply with it. In this regard, s. 54(1)(b) of the Water Act authorizes amendments on application by the licensee to, among other things, add terms and conditions to a licence. ${ }^{146}$

With respect to both avenues, the Framework should be revised to delete the statement that pre-1977 licences are not subject to s. 35 of the Fisheries Act, for the reasons earlier set out in this article.

Since writing this article the Alberta Land Stewardship Act, S.A. 2009, c. A-26.8 [ALSA] came into effect. ALSA, together with the Framework, supra note 11, released in December 2008, were designed to provide the provincial government with unprecedented legislative and policy tools to comprehensively plan and manage Alberta private and public lands. ALSA contemplates that a regional plan established under the Act may expressly state that a specific statutory consent or class of statutory consent "may be affected" (s. 11). A licence, which would include a Water Act licence, falls under the ALSA definition of "statutory consent" (s. 2(aa)). But this does not necessarily mean that government may unilaterally alter water licences to, for example, require compliance with the Framework and Industry Agreement, if this were a part of a regional plan. Section 17 of $A L S A$ states that if there is a conflict between an Act and a regional plan, the Act prevails. Arguably there is such conflict, as s. 18 of the Water Act, supra note 12, strongly protects the rights of pre-Water Act water licences (issued before 1999). To counter this it could be pointed out that s. 17(4) of ALSA states that if there is a conflict between ALSA and any other Act, $A L S A$ prevails. It then could be argued that s. 11 of $A L S A$ prevails over s. 18 of the Water Act. In the end a court might have to decide the issue and in making its decision it would likely consider which Act is more specific, retroactivity, retrospectivity, and vested rights. 